\title{
Synthesis of Precursors of the Agalacto (Exo) Fragment of the Quartromicins via an Auxiliary-Controlled Exo-Selective Diels-Alder Reaction
}

\author{
Jun $\mathrm{Qi}^{\mathrm{a}}$ and William R. Roush*b \\ ${ }^{a}$ Department of Chemistry, University of Michigan, Ann Arbor, MI 48109 and \\ ${ }^{\mathrm{b}}$ Department of Chemistry, Scripps-Florida, Jupiter, FL 33458
}

Email: roush@scripps.edu

Supporting Information-Part 1

Experimental Procedures and Tabulated Spectroscopic Data 
General Methods: All reaction solvents were purified before use. Tetrahydrofuran, dichloromethane, and toluene were purified by passing through a solvent column composed of activated A-1 alumina. Unless indicated otherwise, all commercial reagents were used as purchased without further purification.

Physical Properties and Spectroscopic Measurements: Proton nuclear magnetic resonance $\left({ }^{1} \mathrm{H}\right.$ NMR) spectra and carbon-13 $\left({ }^{13} \mathrm{C}\right.$ NMR) spectra were recorded on a Varian Inova500 spectrometer at $500 \mathrm{MHz}$ and $125 \mathrm{MHz}$, respectively, or a Varian Inova-400 spectrometer at $400 \mathrm{MHz}$ and $100 \mathrm{MHz}$, respectively. The proton signal of residual, non-deuterated solvent ( $\square 7.26$ for $\mathrm{CHCl}_{3}$ ) was used as an internal reference for ${ }^{1} \mathrm{H}$ spectra. For ${ }^{13} \mathrm{C}$ spectra, chemical shifts are reported relative to the $\mathrm{Q} 77.00$ resonance of $\mathrm{CDCl}_{3}$. Coupling constants are reported in $\mathrm{Hz}$. Infrared (IR) spectra were recorded on a ZVG 70-250-S spectrometer manufactured by Micromass Corp. (Manchester, UK).

Analytical thin layer chromatography (TLC) was performed on Kieselgel $60 \mathrm{~F}_{254}$ glass plates precoated with a $0.25 \mathrm{~mm}$ thickness of silica gel. The TLC plates were visualized with UV light and/or by staining with Cerium Molybdate stain (Hanessian's Stain: $5.0 \mathrm{~g} \mathrm{Ce}\left(\mathrm{SO}_{4}\right)_{2}, 25.0 \mathrm{~g}$ $\left(\mathrm{NH}_{4}\right) \mathrm{Mo}_{7} \mathrm{O}_{24} \cdot 4 \mathrm{H}_{2} \mathrm{O}, 450 \mathrm{~mL} \mathrm{H} 2 \mathrm{O}, 50 \mathrm{~mL} \mathrm{H}_{2} \mathrm{SO}_{4}$ ). Column chromatography was performed using Kieselgel 60 (230-400 mesh) silica gel.

HPLC purifications were performed using an HPLC system composed of two Rainin HPXL pumps connected to various Dynamax ${ }^{\circledR}$ axial compression columns packed with Rainin $60 \AA$ irregular silica gel. Samples were loaded into the system with a $2 \mathrm{~mL}$ Rheodyne 7125 injector and were detected using a Rainin Dynamax ${ }^{\circledR}$ UV-C detector. Integration of the various signals was performed using the reprocessing program within the Dynamax ${ }^{\circledR}$ HPLC Method Manager. 


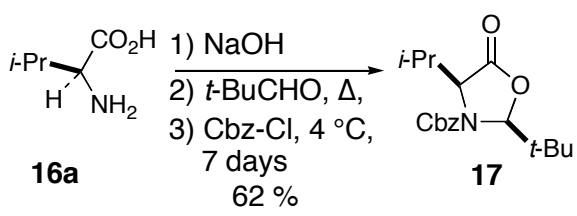

\section{(2S, 4S)-2-tert-Butyl-4-isopropyl-5-oxo-oxazolidine-3-carboxylic acid benzyl ester (17).} Aqueous $\mathrm{NaOH}$ solution $\left(8.54 \mathrm{~g}, 0.21 \mathrm{~mol}\right.$ in $40 \mathrm{~mL}$ of water) was added to a $23{ }^{\circ} \mathrm{C}$ solution of Lvaline 16a (25 g, $0.21 \mathrm{~mol})$ in $400 \mathrm{~mL}$ of ethanol. The mixture was stirred for $1 \mathrm{~h}$ after the reaction became homogeneous and was then concentrated in vacuo. The resulting solid was dried overnight under high vacuum. To this solid was added $500 \mathrm{~mL}$ of pentane and pivalaldehyde (27.6 g, $0.32 \mathrm{~mol}$ ) and the mixture was heated at reflux overnight with a Dean-Stark apparatus. Approximately $15 \mathrm{~mL}$ of water was collected. The solvent was removed in vacuo and the crude material was co-evaporated with benzene twice to yield the imine intermediate. To a $0{ }^{\circ} \mathrm{C}$ mixture of this material in $500 \mathrm{~mL}$ of $\mathrm{CH}_{2} \mathrm{Cl}_{2}$ was added benzyl chloroformate $(\mathrm{CbzCl})(45.8 \mathrm{~mL}, 0.32 \mathrm{~mol})$. The mixture was kept at $4{ }^{\circ} \mathrm{C}$ for $7 \mathrm{~d}$. The mixture was then partitioned between $\mathrm{CH}_{2} \mathrm{Cl}_{2}(300 \mathrm{~mL})$ and brine $(300 \mathrm{~mL})$. The layers were separated and the aq. layer extracted with $\mathrm{CH}_{2} \mathrm{Cl}_{2}$. The combined organic extracts were washed with aq. saturated $\mathrm{NaHCO}_{3}$ and brine, then dried with $\mathrm{MgSO}_{4}$, filtered, and concentrated in vacuo. The crude product was purified by flash chromotography on silica gel (10\% EtOAc-hexanes) to afford compound $\mathbf{1 7}$ in $68 \%$ yield as a single diastereomers: $\mathrm{R}_{\mathrm{f}}=0.22$ (10\% EtOAc-hexane); m.p. $71-73{ }^{\circ} \mathrm{C}$; $[\square]^{23}{ }_{\mathrm{D}}=+14.7{ }^{\circ}(c)$, $\left.\mathrm{CH}_{2} \mathrm{Cl}_{2}\right)$; ${ }^{1} \mathrm{H}$ NMR $\left(500 \mathrm{MHz}, \mathrm{CDCl}_{3}\right) \square 7.39(\mathrm{~m}, 5 \mathrm{H}), 5.56(\mathrm{~s}, 1 \mathrm{H}), 5.18(\mathrm{~s}, 2 \mathrm{H}), 4.00(\mathrm{~d}, J=$ $11.2 \mathrm{~Hz}, 1 \mathrm{H}), 2.02(\mathrm{~m}, 1 \mathrm{H}), 1.25(\mathrm{~d}, J=6.3 \mathrm{~Hz}, 3 \mathrm{H}), 1.06(\mathrm{~d}, J=6.8 \mathrm{~Hz}, 3 \mathrm{H}), 0.98(\mathrm{~s}, 9 \mathrm{H}) ;{ }^{13} \mathrm{C}$ NMR (500 MHz, $\left.\mathrm{CDCl}_{3}\right) \square 172.2,156.7,135.3,128.7,128.6,128.4,96.3,68.5,62.0,36.6,32.0$, 25.0, 19.8, 19.6; FT-IR (thin film) 2971, 1791, 1719, 1482, 1469, 1456, 1391, 1347, 1322, 1245 , 1227, 1197, 1108, 1047, 987, $924 \mathrm{~cm}^{-1}$; HRMS (ESI) for $\mathrm{C}_{18} \mathrm{H}_{25} \mathrm{NO}_{4} \mathrm{Na}[\mathrm{M}+\mathrm{Na}]^{+}$calcd. 342.1681, found $342.1689 \mathrm{~m} / \mathrm{z}$.

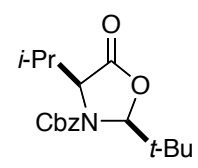

17

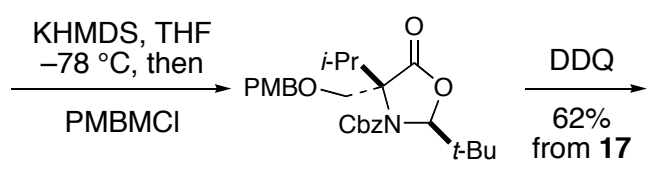

37

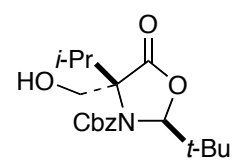

18 


\section{(2S, 4R)-2-tert-Butyl-4-isoporpyl-4-(4-methoxy-benzyloxymethyl)-5-oxo-oxazolidine-3-}

carboxylic acid benzyl ester (37). To a $-78^{\circ} \mathrm{C}$ solution of $17(18.6 \mathrm{~g}, 58 \mathrm{mmol})$ in $290 \mathrm{~mL}$ of THF was slowly added $140 \mathrm{~mL}$ of $0.5 \mathrm{M}$ KHMDS in toluene $(70 \mathrm{mmol})$. The resulting solution was stirred at $-78^{\circ} \mathrm{C}$ for $30 \mathrm{~min}$, and then freshly prepared $\mathrm{PMBMCl}^{1}(21.2 \mathrm{~g}, 116 \mathrm{mmol})$ was added via cannula. The reaction was kept at $-78{ }^{\circ} \mathrm{C}$ for $30 \mathrm{~min}$, then slowly warmed to $-30{ }^{\circ} \mathrm{C}$. Next, $200 \mathrm{~mL}$ of $10 \% \mathrm{NaHSO}_{4}$ solution was added. The layers were separated, and the aqueous layer was extracted with EtOAc $(3 \mathrm{x})$. The combined organic layers were washed with saturated aq. $\mathrm{NaHCO}_{3}$, and brine, dried over $\mathrm{MgSO}_{4}$, filtered and concentrated. The crude product was purified by silica gel flash chromatography to give $23.5 \mathrm{~g}$ of a mixture of $\mathbf{3 7}$ and starting material 17, which only can be partially separated by preparation HPLC. This mixture was used directly in next step. Characterization data for 37: $\mathrm{R}_{\mathrm{f}}=0.22\left(10 \%\right.$ EtOAc-hexane); $[\square]^{23} \mathrm{D}=-9.2^{\circ}\left(\right.$ c $\left.2.0, \mathrm{CH}_{2} \mathrm{Cl}_{2}\right) ;{ }^{1} \mathrm{H}$ $\operatorname{NMR}\left(500 \mathrm{MHz}, \mathrm{CDCl}_{3}\right) \square 7.31(\mathrm{~m}, 5 \mathrm{H}), 7.11(\mathrm{~d}, J=8.3 \mathrm{~Hz}, 2 \mathrm{H}), 6.85(\mathrm{~d}, J=8.3 \mathrm{~Hz}, 2 \mathrm{H}), 5.62$ $(\mathrm{s}, 1 \mathrm{H}), 5.16(\mathrm{~d}, J=12.2 \mathrm{~Hz}, 1 \mathrm{H}), 4.98(\mathrm{~d}, J=12.2 \mathrm{~Hz}, 1 \mathrm{H}), 4.27(\mathrm{~d}, J=11.7 \mathrm{~Hz}, 1 \mathrm{H}), 4.22(\mathrm{~d}, J$ $=11.7 \mathrm{~Hz}, 1 \mathrm{H}), 4.12(\mathrm{~m}, 1 \mathrm{H}), 3.80(\mathrm{~s}, 3 \mathrm{H}), 3.74(\mathrm{~d}, J=8.8 \mathrm{~Hz}, 1 \mathrm{H}), 2.28(\mathrm{~m}, 1 \mathrm{H}), 1.12(\mathrm{t}, J=$ $7.8 \mathrm{~Hz}, 6 \mathrm{H}), 0.99$ (s, $9 \mathrm{H}), ;{ }^{13} \mathrm{C} \mathrm{NMR}\left(500 \mathrm{MHz}, \mathrm{CDCl}_{3}\right) \square 173.8,159.1,135.4,129.7,128.8$, 128.6, 128.4, 113.7, 95.6, 72.6, 70.0, 67.7, 55.2, 37.4, 33.8, 25.8, 18.8, 17.9; FT-IR (thin film) 2964, 2882, 2837, 1788, 1720, 1613, 1586, 1514, 1466, 1482, 1390, 1369, 1356, 1249, 1221, 1192, 1099 , 1039, 1014, $824 \mathrm{~cm}^{-1}$; HRMS (ESI) for $\mathrm{C}_{27} \mathrm{H}_{35} \mathrm{NO}_{6} \mathrm{Na}[\mathrm{M}+\mathrm{Na}]^{+}$calcd. 492.2362, found 492.2384 $\mathrm{m} / \mathrm{z}$.

(2S, 4R)-2-tert-Butyl-4-hydroxymethyl-4-isopropyl-5-oxo-oxazolidine-3-carboxylic acid benzyl ester (18). To a solution of the mixture of 17 and $\mathbf{3 7}$ from the preceding experiment $(23.5 \mathrm{~g})$ in $340 \mathrm{~mL}$ of $\mathrm{CH}_{2} \mathrm{Cl}_{2}$ and $20 \mathrm{~mL}$ of $\mathrm{H}_{2} \mathrm{O}$ was added $14.4 \mathrm{~g}(63 \mathrm{mmol})$ of DDQ. The reaction mixture was stirred at $23{ }^{\circ} \mathrm{C}$ overnight. Saturated aq. $\mathrm{NaHCO}_{3}$ was then added. The layers were separated, and the aqueous layer was extracted with $\mathrm{CH}_{2} \mathrm{Cl}_{2}(2 \mathrm{x})$. The combined organic layers were washed with brine, dried over $\mathrm{MgSO}_{4}$, filtered and concentrated. The crude product was purified by flash chromatography on silica gel to give $12.6 \mathrm{~g}$ of 18 (62\% yield for 2 steps) along with $6.0 \mathrm{~g}(32 \%)$ of recovered 17. Data for 18: $\mathrm{R}_{\mathrm{f}}=0.32\left(25 \%\right.$ EtOAc-hexane); $[\square]^{23}{ }_{\mathrm{D}}=+4.7^{\circ}(c$ 3.5, $\left.\mathrm{CH}_{2} \mathrm{Cl}_{2}\right) ;{ }^{1} \mathrm{H}$ NMR $\left(500 \mathrm{MHz}, \mathrm{CDCl}_{3}\right) \square 7.33(\mathrm{~m}, 5 \mathrm{H}), 5.60(\mathrm{~s}, 1 \mathrm{H}), 5.16(\mathrm{~d}, J=11.7 \mathrm{~Hz}, 1$ H), $5.11(\mathrm{~d}, J=12.4 \mathrm{~Hz}, 1 \mathrm{H}), 4.29(\mathrm{~d}, J=10.3 \mathrm{~Hz}, 1 \mathrm{H}), 3.93(\mathrm{~d}, J=11.0 \mathrm{~Hz}, 1 \mathrm{H}), 2.21(\mathrm{~m}, 1 \mathrm{H})$, $1.66(\mathrm{br}, 1 \mathrm{H}), 1.07$ (d, $J=8.1 \mathrm{~Hz}, 6 \mathrm{H}), 0.94$ (s, $9 \mathrm{H}) ;{ }^{13} \mathrm{C} \mathrm{NMR}\left(500 \mathrm{MHz}, \mathrm{CDCl}_{3}\right) \square 174.1,156.1$, 
135.4, 128.7, 128.6, 128.5, 95.7, 71.0, 67.9, 61.5, 37.4, 33.9, 25.8, 18.7, 17.7; FT-IR (thin film) $3479,2970,2912,1787,1715,1482,1470,1457,1400,1370,1324,1272,1191,1058,1036,1013$ $\mathrm{cm}^{-1}$; HRMS (ESI) for $\mathrm{C}_{19} \mathrm{H}_{27} \mathrm{NO}_{5} \mathrm{Na}[\mathrm{M}+\mathrm{Na}]^{+}$calcd. 372.1787 , found $372.1785 \mathrm{~m} / \mathrm{z}$.

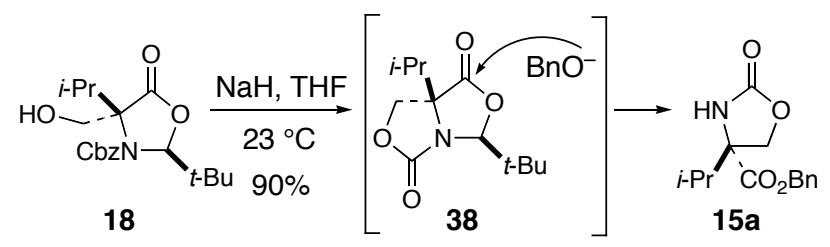

(4R)-4-Isopropyl-2-oxo-oxazolidine-4-carboxylic acid benzyl ester (15a). To a $0{ }^{\circ} \mathrm{C}$ solution of $18(3.45 \mathrm{~g}, 9.9 \mathrm{mmol})$ in THF (100 mL) was added NaH (284 mg, $11.8 \mathrm{mmol})$. The reaction was warmed to room temperature and stirred for $3 \mathrm{~h}$, at which point $\mathrm{pH} 7$ buffer $(50 \mathrm{~mL})$ was slowly added. The layers were separated and the aqueous layer was extracted with diethyl ether $(3 \mathrm{x})$. The combined organic layers were washed with brine, dried over $\mathrm{MgSO}_{4}$, filtered and concentrated. Purification of the crude product by flash chromatography on silica gel (50\% EtOAchexane) provided 15a $(2.34 \mathrm{~g} 90 \%)$ as a colorless oil: $\mathrm{R}_{\mathrm{f}}=0.23\left(50 \%\right.$ EtOAc-hexane); $[\square]_{\mathrm{D}}^{23}=$ $+10.2^{\circ}\left(\mathrm{c} 1.4, \mathrm{CH}_{2} \mathrm{Cl}_{2}\right) ;{ }^{1} \mathrm{H}$ NMR $\left(500 \mathrm{MHz}, \mathrm{CDCl}_{3}\right) \square 7.40(\mathrm{~m}, 5 \mathrm{H}), 6.28$ (br, $\left.1 \mathrm{H}\right), 5.23(\mathrm{~d}, J=$ $12.0 \mathrm{~Hz}, 1 \mathrm{H}), 5.19$ (d, $J=12.0 \mathrm{~Hz}, 1 \mathrm{H}), 4.60$ (d, $J=9.5 \mathrm{~Hz}, 1 \mathrm{H}), 4.27$ (d, $J=9.5 \mathrm{~Hz}, 1 \mathrm{H}), 2.13$ $(\mathrm{m}, 1 \mathrm{H}), 0.94(\mathrm{~d}, J=6.5 \mathrm{~Hz}, 3 \mathrm{H}), 0.89(\mathrm{~d}, J=7.0 \mathrm{~Hz}, 3 \mathrm{H}) ;{ }^{13} \mathrm{C} \mathrm{NMR}\left(500 \mathrm{MHz}, \mathrm{CDCl}_{3}\right) \square 171.5$, 158.2, 134.6, 128.8, 128.7, 128.6, 69.8, 67.8, 67.4, 34.6, 16.8, 16.1; FT-IR (thin film) 3251, 2970, 1760, 1739, 1265, 1215, 1193, 1136, 1035, 950, 742, $698 \mathrm{~cm}^{-1}$; HRMS (ESI) for $\mathrm{C}_{14} \mathrm{H}_{17} \mathrm{NO}_{4} \mathrm{Na}$ $[\mathrm{M}+\mathrm{Na}]^{+}$calcd. 286.1055, found $286.1054 \mathrm{~m} / \mathrm{z}$.

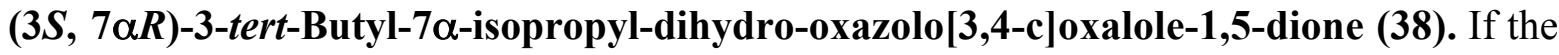
reaction was quenched right after the addition of $\mathrm{NaH}$, a mixture of $\mathbf{3 8}$ and 15a was obtained. Separation of this mixture by chromatography on silica gel provided samples of 38: $\mathrm{R}_{\mathrm{f}}=0.36(25 \%$ EtOAc-hexane); $[\square]^{23}{ }_{\mathrm{D}}=-49^{\circ}\left(c \mathrm{1.3}, \mathrm{CH}_{2} \mathrm{Cl}_{2}\right)$; m. p. 150-152 ${ }^{\circ} \mathrm{C} ;{ }^{1} \mathrm{H} \mathrm{NMR}\left(500 \mathrm{MHz}, \mathrm{CDCl}_{3}\right)$ $5.30(\mathrm{~s}, 1 \mathrm{H}), 4.52(\mathrm{~d}, J=9.8 \mathrm{~Hz}, 1 \mathrm{H}), 4.41(\mathrm{~d}, J=9.8 \mathrm{~Hz}, 1 \mathrm{H}), 2.26(\mathrm{~m}, 1 \mathrm{H}), 1.16(\mathrm{~d}, J=6.8 \mathrm{~Hz}, 3$ H), $1.10(\mathrm{~d}, J=6.8 \mathrm{~Hz}, 3 \mathrm{H}), 1.06(\mathrm{~s}, 9 \mathrm{H}) ;{ }^{13} \mathrm{C} \mathrm{NMR}\left(500 \mathrm{MHz}, \mathrm{CDCl}_{3}\right) \square$ 188.0, 172.6, 162.4, 99.7, 67.0, 35.6, 32.5, 24.8, 15.3, 15.2; FT-IR (thin film) 2977, 1790, 1732, 1492, 1375, 1336, 1274 , 
1239, 1183, 1084, 944, $913 \mathrm{~cm}^{-1}$; HRMS (ESI) for $\mathrm{C}_{12} \mathrm{H}_{19} \mathrm{NO}_{4} \mathrm{Na}[\mathrm{M}+\mathrm{Na}]^{+}$calcd. 264.1212 found $264.1212 \mathrm{~m} / \mathrm{z}$.

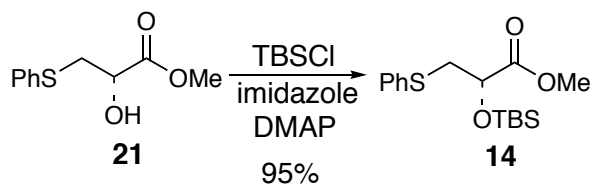

(2S)-2-(tert-Butyl-dimethylsilanyloxy)-3-phenylsulfanyl-propionic acid methyl ester (14). To a solution of alcohol 21 (8.88 g, $41.9 \mathrm{mmol})$, imidazole (7.13 g, $105 \mathrm{mmol})$ and DMAP $(0.21 \mathrm{~g}, 1.6 \mathrm{mmol})$ in $\mathrm{CH}_{2} \mathrm{Cl}_{2}$ was added TBSCl $(7.58 \mathrm{~g}, 50.2 \mathrm{mmol})$. The reaction was stirred at room temperature overnight. Diethyl ether $(200 \mathrm{~mL})$ and water $(200 \mathrm{~mL})$ were then added, and the layers were separated. The aqueous layer was extracted twice with diethyl ether. The combined organic layers were washed with $1 \mathrm{~N} \mathrm{HCl}$, saturated aq. $\mathrm{NaHCO}_{3}$ solution, and brine, and dried over $\mathrm{MgSO}_{4}$. The mixture was filtered, and the filtrate concentrated in vacuo. The crude product was purified by chromatography on silica gel (20\% $\mathrm{Et}_{2} \mathrm{O}$-hexane) to afford 14 (13.0 g, 95\% yield) as a colorless oil: $\mathrm{R}_{\mathrm{f}}=0.75\left(20 \% \mathrm{Et}_{2} \mathrm{O}\right.$-hexane); []$^{23}{ }_{\mathrm{D}}=+1.7^{\circ}\left(c 0.75, \mathrm{CH}_{2} \mathrm{Cl}_{2}\right) ;{ }^{1} \mathrm{H} \mathrm{NMR}(500 \mathrm{MHz}$, $\left.\mathrm{CDCl}_{3}\right) \square 7.30(\mathrm{~m}, 5 \mathrm{H}), 4.35(\mathrm{dd}, J=7.0,5.0 \mathrm{~Hz}, 1 \mathrm{H}), 3.72(\mathrm{~s}, 3 \mathrm{H}), 3.35(\mathrm{dd}, J=13.5,5.0 \mathrm{~Hz}, 1$ H), $3.17(\mathrm{dd}, J=13.5,7.5 \mathrm{~Hz}, 1 \mathrm{H}), 0.89$ (s, $9 \mathrm{H}), 0.06$ (s, $3 \mathrm{H}), 0.05$ (s, $3 \mathrm{H}) ;{ }^{13} \mathrm{C} \mathrm{NMR}(500 \mathrm{MHz}$, $\left.\mathrm{CDCl}_{3}\right) \square 172.4,135.9,129.6,128.9,126.3,71.9,52.1,38.9,25.7,18.3,-5.0,-5.2$; FT-IR (thin film) 2952, 2930, 2887, 2857, 1758, 1584,1481, 1472, 1463, 1438, 1257, 1135, 1024, 838, 780, 691 $\mathrm{cm}^{-1}$; HRMS (ESI) for $\mathrm{C}_{16} \mathrm{H}_{26} \mathrm{O}_{3} \mathrm{SSiNa}[\mathrm{M}+\mathrm{Na}]^{+}$calcd. 349.1270 , found $349.1263 \mathrm{~m} / \mathrm{z}$.

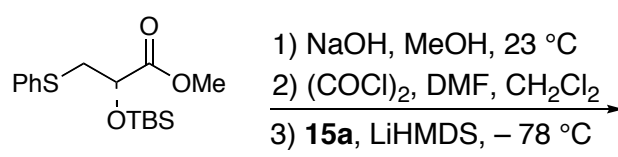

14

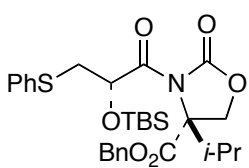

23a

\section{(2S, 4R)-3-[2-(tert-Butyl-dimethyl-silanyloxy)-3-phenylsulfanyl-propionyl]-4-isopropyl-} 2-oxo-oxazolidine-4-carboxylic acid benzyl ester (23a). To a solution of 14 (3.3 g, $10 \mathrm{mmol})$ in methanol $(20 \mathrm{~mL})$ was added $3 \mathrm{~N}$ aq. $\mathrm{NaOH}(15 \mathrm{~mL}, 45 \mathrm{mmol})$. The resulting mixture was stirred at room temperature for $1.5 \mathrm{~h}$. The mixture was diluted with $50 \mathrm{~mL}$ of water, then was acidified to $\mathrm{pH}$ 
3 using $1 \mathrm{~N} \mathrm{HCl}$. The aqueous layer was extracted with diethyl ether $(3 \mathrm{x})$. The combined organic layers were washed with brine and dried over $\mathrm{MgSO}_{4}$. The mixture was filtered and then concentrated in vacuo to give the crude carboxylic acid that was used directly in the next step.

The carboxylic acid was dissolved in $\mathrm{CH}_{2} \mathrm{Cl}_{2}(20 \mathrm{~mL})$. Oxalyl chloride $(1.8 \mathrm{~mL}, 20 \mathrm{mmol})$ was then added, followed by 2 drops of DMF. The reaction was stirred at room temperature for $1 \mathrm{~h}$. The solvent was removed in vacuo, and the resulting residue was azeotroped with benzene $(20 \mathrm{~mL})$. The resulting acid chloride $\mathbf{2 2}$ was used directly in the next step without further purification.

To a $-78{ }^{\circ} \mathrm{C}$ solution of oxazolidinone $15 \mathrm{a}(2.0 \mathrm{~g}$. $7.6 \mathrm{mmol})$ in THF $(30 \mathrm{~mL})$ was added a 1.0 M solution of LiHMDS in THF (1.4 g in $8.5 \mathrm{~mL}, 8.5 \mathrm{mmol})$ via cannula. The resulting mixture was stirred at $-78{ }^{\circ} \mathrm{C}$ for another $30 \mathrm{~min}$, and then a solution of the acid chloride 22 in THF $(20 \mathrm{~mL})$ was added via cannula. The reaction was then slowly warmed to room temperature overnight. Saturated aq. $\mathrm{NH}_{4} \mathrm{Cl}$ solution $(25 \mathrm{~mL})$ was then added, followed by diethyl ether $(15 \mathrm{~mL})$. The layers were separated, and the aqueous layer was extracted with diethyl ether $(30 \mathrm{~mL} \square 3)$. The combined organic layers were washed with brine and dried over $\mathrm{MgSO}_{4}$, filtered and concentrated. The crude product was purified by flash chromatography on silica gel to give compound $23 \mathrm{a}(3.4 \mathrm{~g}$, $81 \%)$ as colorless crystals: $\mathrm{R}_{\mathrm{f}}=0.33\left(20 \%\right.$ EtOAc-hexane); m.p. $56-57^{\circ} \mathrm{C}$; $[\square]^{23}{ }_{\mathrm{D}}=-25.6^{\circ}(c 1.6$, $\left.\mathrm{CH}_{2} \mathrm{Cl}_{2}\right) ;{ }^{1} \mathrm{H} \mathrm{NMR}\left(500 \mathrm{MHz}, \mathrm{CDCl}_{3}\right) \square 7.29(\mathrm{~m}, 10 \mathrm{H}), 5.54(\mathrm{dd}, J=6.8,5.8 \mathrm{~Hz}, 1 \mathrm{H}), 5.22(\mathrm{~d}, J=$ $12.2 \mathrm{~Hz}, 1 \mathrm{H}), 5.15$ (d, $J=11.7 \mathrm{~Hz}, 1 \mathrm{H}), 4.35$ (d, $J=9.3 \mathrm{~Hz}, 1 \mathrm{H}), 4.28$ (d, $J=9.3 \mathrm{~Hz}, 1 \mathrm{H}), 3.23$ $(\mathrm{dd}, J=13.7,5.8 \mathrm{~Hz}, 1 \mathrm{H}), 3.09(\mathrm{~m}, 1 \mathrm{H}), 2.84(\mathrm{dd}, J=13.7,6.8 \mathrm{~Hz}, 1 \mathrm{H}), 1.13(\mathrm{~d}, J=6.8 \mathrm{~Hz}, 3 \mathrm{H})$, $0.93(\mathrm{~d}, J=7.3 \mathrm{~Hz}, 3 \mathrm{H}), 0.87$ (s, 9H), 0.03 (s, $6 \mathrm{H}) ;{ }^{13} \mathrm{C} \mathrm{NMR}\left(500 \mathrm{MHz}, \mathrm{CDCl}_{3}\right) \square 172.4,169.4$, 153.3, 136.4, 134.9, 130.4, 129.1, 129.0, 128.9, 128.8, 126.6, 70.8, 69.4, 68.3, 66.2, 38.4, 29.3, 25.9, 18.4, 17.3, 17.1, -4.6, -4.8; FT-IR (thin film) 2956, 2930, 2885, 2857, 1789, 1756, 1717, 1463, 1481, 1472, 1386, 1271, 1215, 1109, 1091, 838, 779, 742, $697 \mathrm{~cm}^{-1}$; HRMS (ESI) for $\mathrm{C}_{29} \mathrm{H}_{39} \mathrm{NO}_{6} \mathrm{SSiNa}[\mathrm{M}+\mathrm{Na}]^{+}$calcd. 580.2165 , found $580.2169 \mathrm{~m} / \mathrm{z}$.

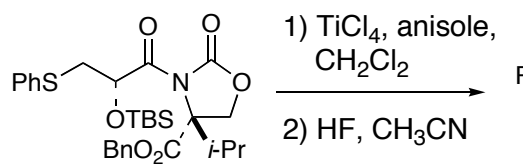

23a

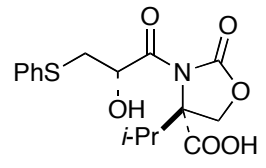

24a

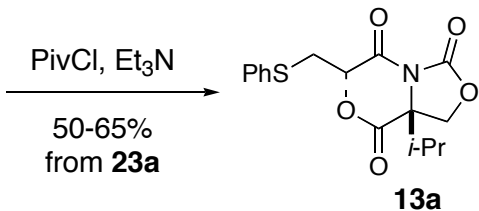

$13 a$

$(6 S, 8 \square R)-8 \square-I s o p r o p y l-6-p h e n y l s u l f a n y l m e t h y l-d i h y d r o-o x a z o l o[4,3-c]-[1,4]$ oxazine-

3,5,8-trione (13a). To a $0{ }^{\circ} \mathrm{C}$ solution of 23a $(3.4 \mathrm{~g}, 6.1 \mathrm{mmol})$ in $61 \mathrm{~mL}$ of $\mathrm{CH}_{2} \mathrm{Cl}_{2}$ was added SI-7 
anisole $(5.4 \mathrm{~mL}, 49 \mathrm{mmol})$ followed by the dropwise addition of $1 \mathrm{M}$ solution of $\mathrm{TiCl}_{4}$ in $\mathrm{CH}_{2} \mathrm{Cl}_{2}$ $(24 \mathrm{~mL}, 24 \mathrm{mmol})$. The reaction mixture was warmed to room temperature and stirred for another 2 $\mathrm{h}$, then was then poured into $40 \mathrm{~g}$ of ice and $40 \mathrm{~mL}$ of $1 \mathrm{~N} \mathrm{HCl}$. The layers were separated and the aqueous layer was extracted with $\mathrm{CH}_{2} \mathrm{Cl}_{2}(30 \mathrm{~mL} \square 3)$. The combined organic layers were washed with brine, dried over $\mathrm{MgSO}_{4}$, filtered and concentrated. The crude product was used in next step without further purification.

The crude product from above was dissolved in $50 \mathrm{~mL}$ of $\mathrm{CH}_{3} \mathrm{CN}$, and $5 \mathrm{~mL}$ of $48 \%$ hydrofluoric acid was added. The mixture was stirred at room temperature for $2 \mathrm{~h}$, then $20 \mathrm{~mL}$ of water was added. The aqueous layer was extracted with diethyl ether (20 mL $\square 3)$. The combined ether layers were washed with saturated aq. $\mathrm{NaHCO}_{3}(3 \mathrm{x})$. The combined $\mathrm{NaHCO}_{3}$ extracts were slowly acidified to $\mathrm{pH} \square 3$ using $1 \mathrm{~N} \mathrm{HCl}$ and were then extracted with diethyl ether $(150 \mathrm{~mL} \square 3)$. The combined ether layers were washed with brine and dried over $\mathrm{MgSO}_{4}$, filtered and concentrated to afford compound 24a. The crude hydroxy acid 24a (about $1.8 \mathrm{~g}$ ) was azeotropically dried with benzene $(2 \times 20 \mathrm{~mL})$ and used in the next step without further purification.

A solution of the above hydroxy acid 24a in THF $(60 \mathrm{~mL})$ was treated with triethylamine $(0.87 \mathrm{~mL}, 6.2 \mathrm{mmol})$. Pivalyl chloride $(0.74 \mathrm{~mL}, 6.2 \mathrm{mmol})$ was then added. The reaction was stirred overnight at room temperature, and a white precipitate was observed. The precipitate was filtered, and the filtrate was concentrated approximately to half of its original volume. Pentane was slowly added to the solution, and compound 13a was precipitated as white crystals and collected by suction filtration. The yield of $13 \mathbf{a}(1.3 \mathrm{~g})$ was $64 \%$ over three steps: m.p. $128-130{ }^{\circ} \mathrm{C}$; $[\square]^{23}{ }_{\mathrm{D}}=$ $+69.5^{\circ}\left(c 4.0, \mathrm{CH}_{2} \mathrm{Cl}_{2}\right) ;{ }^{1} \mathrm{H}$ NMR $\left(500 \mathrm{MHz}, \mathrm{CDCl}_{3}\right) \square 7.30(\mathrm{~m}, 5 \mathrm{H}), 5.11(\mathrm{dd}, J=6.6,3.7 \mathrm{~Hz}, 1$ H), $4.48(\mathrm{~d}, J=10.3 \mathrm{~Hz}, 1 \mathrm{H}), 4.39$ (d, $J=9.5 \mathrm{~Hz}, 1 \mathrm{H}), 3.68(\mathrm{dd}, J=14.7,3.7 \mathrm{~Hz}, 1 \mathrm{H}), 3.42(\mathrm{dd}, J$ $=14.7,6.6 \mathrm{~Hz}, 1 \mathrm{H}), 2.25(\mathrm{~m}, 1 \mathrm{H}), 1.04(\mathrm{~d}, J=4.4 \mathrm{~Hz}, 3 \mathrm{H}), 1.03(\mathrm{~d}, J=5.1 \mathrm{~Hz}, 3 \mathrm{H}) ;{ }^{13} \mathrm{C} \mathrm{NMR}$ $\left(500 \mathrm{MHz}, \mathrm{CDCl}_{3}\right) \square 165.5,161.9,149.2,134.6,131.1,129.5,127.7,78.2,66.3,65.6,35.7,33.7$, 16.3, 15.5; FT-IR (thin film) 1974, 1821, 1754, 1721, 1483, 1366, 1298, 1207, 1172, 1054, 760, 738 $\mathrm{cm}^{-1}$; HRMS (ESI) for $\mathrm{C}_{16} \mathrm{H}_{17} \mathrm{NO}_{5} \mathrm{SNa}[\mathrm{M}+\mathrm{Na}]^{+}$calcd. 358.0725 , found $358.0718 \mathrm{~m} / \mathrm{z}$.

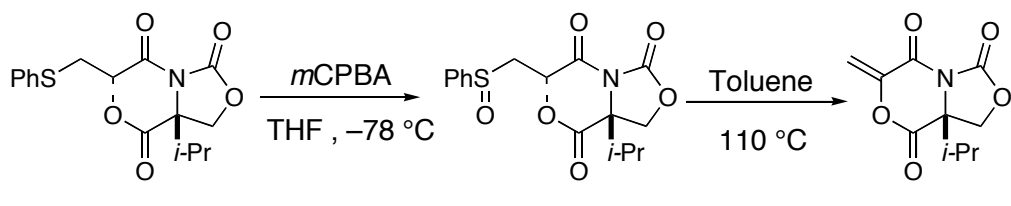

$$
13 a
$$

39

$12 a$

SI-8 


\section{$(6 S, 8 \square R)$-6-Benzenesulfinylmethyl-8 $\square$-isopropyl-dihydro-oxazolo $[4,3-c][1,4]$ oxazine-}

3,5,8-trione (39). To a $-78{ }^{\circ} \mathrm{C}$ solution of 13a $(1.3 \mathrm{~g}, 3.9 \mathrm{mmol})$ in $39 \mathrm{~mL}$ of THF was added a solution of $m$ CPBA ( $72 \%$ purity) ( $0.93 \mathrm{~g}, 3.9 \mathrm{mmol}$ in $5 \mathrm{~mL}$ THF) via cannula. The resulting mixture was slowly warmed to room temperature. The solution was concentrated to half volume, and then ether was slowly added to precipitate sulfoxide 39 as white crystals $(1.0 \mathrm{~g}, 80 \%)$ : [0] ${ }^{23} \mathrm{D}=$ $+170^{\circ}\left(c 1.1, \mathrm{CH}_{2} \mathrm{Cl}_{2}\right)$; m.p. $135-137{ }^{\circ} \mathrm{C} ;{ }^{1} \mathrm{H}$ NMR $\left(400 \mathrm{MHz}, \mathrm{CDCl}_{3}\right) \square 7.63(\mathrm{~m}, 5 \mathrm{H}), 5.59$ (dd, $J$ $=10.3,2.2 \mathrm{~Hz}, 1 \mathrm{H}), 4.57(\mathrm{~d}, J=9.5 \mathrm{~Hz}, 1 \mathrm{H}), 4.48(\mathrm{~d}, J=10.3 \mathrm{~Hz}, 1 \mathrm{H}), 3.59(\mathrm{dd}, J=13.9,2.2 \mathrm{~Hz}$, $1 \mathrm{H}), 3.18(\mathrm{dd}, J=13.9,10.3 \mathrm{~Hz}, 1 \mathrm{H}), 2.50(\mathrm{~m}, 1 \mathrm{H}), 1.12(\mathrm{~d}, J=7.3 \mathrm{~Hz}, 6 \mathrm{H}) ;{ }^{13} \mathrm{C}$ NMR $(500$ $\left.\mathrm{MHz}, \mathrm{CDCl}_{3}\right) \square 165.3,161.5,149.1,142.7,132.0,129.8,123.8,72.9,65.9,65.7,57.6,32.6,16.2$, 15.1; FT-IR (thin film) 3060, 2976, 1821, 1769, 1716, 1369, 1297, 1195, 1047, 755, $691 \mathrm{~cm}^{-1}$; HRMS (ESI) for $\mathrm{C}_{16} \mathrm{H}_{17} \mathrm{NO}_{6} \mathrm{SNa}[\mathrm{M}+\mathrm{Na}]^{+}$calcd. 374.0674, found $374.0664 \mathrm{~m} / \mathrm{z}$.

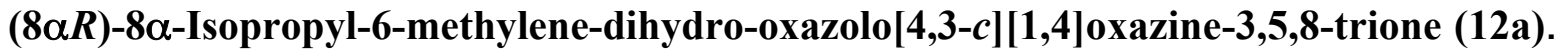
A suspension of sulfoxide $39(745 \mathrm{mg}, 2.0 \mathrm{mmol})$ in toluene $(100 \mathrm{~mL})$ was degassed with argon for $30 \mathrm{~min}$. The reaction was then heated to $110{ }^{\circ} \mathrm{C}$. It was maintained at this temperature for another $30 \mathrm{~min}$. The reaction then was cooled to room temperature, and the solution was reduced to half volume. Pentane was then slowly added to precipitate the product 12a in $90 \%$ yield (405 mg): $[\square]^{23}$ $\mathrm{D}=+1.3^{\circ}\left(c\right.$ 1.5, $\left.\mathrm{CH}_{3} \mathrm{CN}\right)$; m.p. $130-132{ }^{\circ} \mathrm{C} ;{ }^{1} \mathrm{H}$ NMR $\left(400 \mathrm{MHz}, \mathrm{CDCl}_{3}\right) \square 5.98(\mathrm{~d}, J=2.2 \mathrm{~Hz}, 1$ H), $5.51(\mathrm{~d}, J=2.9 \mathrm{~Hz}, 1 \mathrm{H}), 4.54(\mathrm{~d}, J=10.3 \mathrm{~Hz}, 1 \mathrm{H}), 4.40(\mathrm{~d}, J=9.6 \mathrm{~Hz}, 1 \mathrm{H}), 2.23(\mathrm{~m}, 1 \mathrm{H})$, $1.05(\mathrm{~d}, J=6.6 \mathrm{~Hz}, 3 \mathrm{H}), 1.02(\mathrm{~d}, J=6.6 \mathrm{~Hz}, 3 \mathrm{H}) ;{ }^{13} \mathrm{C} \mathrm{NMR}\left(500 \mathrm{MHz}, \mathrm{CDCl}_{3}\right) \quad \square 162.9,146.1$, 134.7, 129.7, 128.3, 109.8, 66.3, 35.6, 16.2, 15.5; FT-IR (thin film) 2975, 1818, 1780, 1708, 1644, $1368,1327,1283,1199,1161,1055,918,775 \mathrm{~cm}^{-1}$; HRMS (ESI) for $\mathrm{C}_{10} \mathrm{H}_{11} \mathrm{NO}_{5} \mathrm{Na}[\mathrm{M}+\mathrm{Na}]^{+}$calcd. 248.0535 , found $248.0537 \mathrm{~m} / \mathrm{z}$.
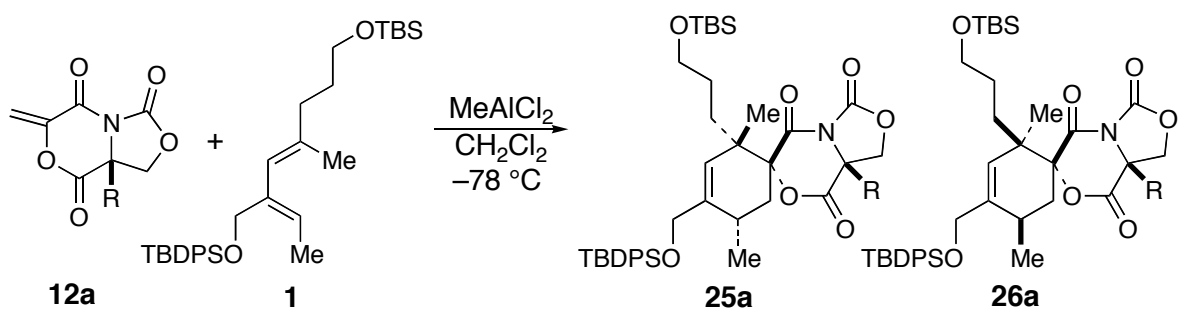

SI-9 
Spiro (1'R, 2'S, 5'S, 8ロR)-6-[2'-[3-(tert-Butyl-dimethyl-silanyloxy)-propyl]-4'-(tertbutyl-diphenyl-silanyloxymethyl)-2',5'-dimethyl-cyclohex-3'-ene]-8 $\square$-isopropyl-dihydrooxazolo $[4,3-c][1,4]$ oxazine-3,5,8-trione (25a) and Spiro (1'R, 2' $R, 5$ ' $R, 8 \square R)-6$-[2'-[3-(tertButyl-dimethyl-silanyloxy)-propyl]-4'-(tert-butyl-diphenyl-silanyloxymethyl)-2',5'-dimethylcyclohex-3'-ene]-8 $\square$-isopropyl-dihydro-oxazolo[4,3-c][1,4]oxazine-3,5,8-trione (26a). To a -78 ${ }^{\circ} \mathrm{C}$ solution of dienophile $12 \mathrm{a}(473 \mathrm{mg}, 2.1 \mathrm{mmol})$ and diene $\mathbf{1}(1.0 \mathrm{~g}, 1.9 \mathrm{mmol})$ in $\mathrm{CH}_{2} \mathrm{Cl}_{2}$ was added $2.7 \mathrm{~mL}$ of $\mathrm{MeAlCl}_{2}(1.0 \mathrm{M}$ solution in hexanes, $2.7 \mathrm{mmol})$. The resulting yellow solution was stirred at $-78{ }^{\circ} \mathrm{C}$ for $5 \mathrm{~d}$. The reaction was quenched by the slow addition of saturated aq. $\mathrm{NaHCO}_{3}$ and allowed to warm to room temperature. The mixture was diluted with diethyl ether and $1 \mathrm{~N} \mathrm{HCl}$, and the layers were separated after the white solids had dissolved. The aqueous layer was extracted with diethyl ether $(3 \mathrm{x})$. The combined organic layers were washed with saturated aq. $\mathrm{NaHCO}_{3}$ and brine, dried over $\mathrm{MgSO}_{4}$, filtered and concentrated. The crude product was then purified by chromatography on silica gel (20\% EtOAc-hexane). The mixture of diasteromeric products so obtained (5 :1 mixture, $1.1 \mathrm{~g}, 70 \%$ ) as inseparable by silica gel chromatography (20\% EtOAchexane), or by HPLC. Data for the mixture of 25a and 26a: $\mathrm{R}_{\mathrm{f}}=0.46\left(33 \%\right.$ EtOAc-hexane); $[\square]^{23}{ }_{\mathrm{D}}$ $=+24.7^{\circ}\left(c 1.8, \mathrm{CH}_{2} \mathrm{Cl}_{2}\right) ;{ }^{1} \mathrm{H}$ NMR for major diastereomer $25 \mathrm{a}\left(500 \mathrm{MHz}, \mathrm{CDCl}_{3}\right) \square 7.51(\mathrm{~m}, 10$ H), $5.40(\mathrm{~s}, 1 \mathrm{H}), 4.37(\mathrm{~s}, 2 \mathrm{H}), 4.13(\mathrm{~m}, 2 \mathrm{H}), 3.54(\mathrm{~m}, 2 \mathrm{H}), 2.66(\mathrm{~m}, 1 \mathrm{H}), 2.34$ (dd, J = 13.9, 7.3 Hz, $1 \mathrm{H}), 2.23$ (m, $1 \mathrm{H}), 1.99$ (dd, $J=13.9,7.3 \mathrm{~Hz}, 1 \mathrm{H}), 1.52$ (m, 4 H), 1.03 (m, $21 \mathrm{H}), 0.84$ (s, 9 $\mathrm{H}), 0.00(\mathrm{~s}, 6 \mathrm{H}) ;{ }^{13} \mathrm{C} \mathrm{NMR}\left(500 \mathrm{MHz}, \mathrm{CDCl}_{3}\right) \square 165.1,164.7,149.5,137.7,135.6,135.5,135.4$, 133.6, 133.5, 129.7, 129.6, 127.7, 127.6, 125.5, 91.6, 66.3, 65.2, 65.0, 63.4, 44.3, 37.7, 37.0, 34.8, 29.0, 27.4, 27.0, 26.8, 26.7, 26.0, 25.9, 21.7, 19.3, 19.2, 18.3, 16.2, 15.7, -5.3; FT-IR (thin film) 2930, 2857, 1822, 1756, 1715, 1472, 1428, 1358, 1297, 1258, 1188, 1111, 1056, 835, 776, $703 \mathrm{~cm}^{-}$ ${ }^{1}$; HRMS (ESI) for $\mathrm{C}_{42} \mathrm{H}_{61} \mathrm{NO}_{7} \mathrm{Si}_{2} \mathrm{Na}[\mathrm{M}+\mathrm{Na}]^{+}$calcd. 770.3884 , found $770.3903 \mathrm{~m} / \mathrm{z}$.

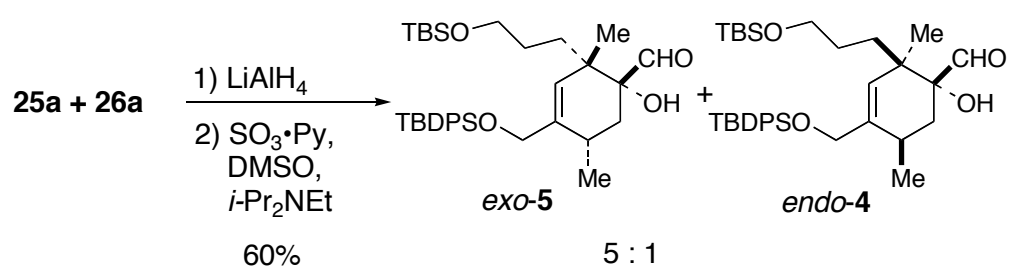

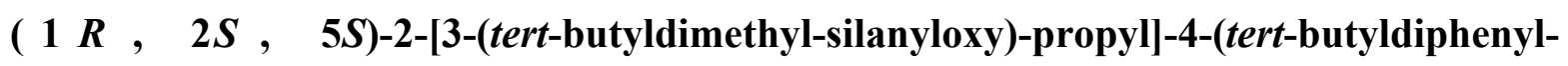
siloxylmethyl)-1-hydroxy-2,5-dimethyl-cyclohex-3-enecarbaldehyde (exo-5) and $(1 R, 2 R, 5 R)$ - 


\section{2-[3-(tert-butyldimethyl-silanyloxy)-propyl]-4-(tert-butyldiphenyl-siloxylmethyl)-1-hydroxy-}

2,5-dimethyl-cyclohex-3-enecarbaldehyde (endo-4). To a solution of the $5: 1$ mixture of 25a and $26 \mathbf{a}(436 \mathrm{mg}, 0.6 \mathrm{mmol})$ in THF (6 mL) was added $\mathrm{LiAlH}_{4}(44 \mathrm{mg}, 1.2 \mathrm{mmol})$. The mixture was stirred at room temperature for $6 \mathrm{~h}$. Diethyl ether and saturated aq. Rochelle's salt solution were then added, and the mixture was further stirred overnight. The layers were separated and the organic layer was extracted with ether $(3 \mathrm{x})$. The combined organic layers was washed with brine, dried over $\mathrm{MgSO}_{4}$, filtered and concentrated. The crude mixture was directly subjected to Parikh-Doering reaction $^{2}$. To a solution of diol mixture $(242 \mathrm{mg}, 0.41 \mathrm{mmol})$ in $\mathrm{CH}_{2} \mathrm{Cl}_{2}(4.1 \mathrm{~mL})$ was added sequentially DMSO (0.29 mL, $4.1 \mathrm{mmol}), i$-Pr $2 \mathrm{NEt}(0.36 \mathrm{~mL}, 2.1 \mathrm{mmol})$, and $\mathrm{SO}_{3} \bullet$ pyridine (196 $\mathrm{mg}, 1.2 \mathrm{mmol}$ ). The reaction was judged complete in $15 \mathrm{~min}$ by TLC and was quenched by addition of EtOAc $(20 \mathrm{~mL})$ and $1 \mathrm{M}$ aq. $\mathrm{HCl}(5 \mathrm{~mL})$. After layer separation the organic layer was washed with saturated aq. $\mathrm{NaHCO}_{3}$, brine, dried with $\mathrm{MgSO}_{4}$, filtered, concentrated, and was purified by chromatography on $\mathrm{SiO}_{2}(10 \%$ EtOAc-hexane) to afford a mixture of the known $\square$ hydroxy aldehyde exo-5 (173 mg, 50\% yield) and endo-4 (35mg, 10\% yield) as an oil, which can be separated by silica gel chromatography. The NMR and HRMS data for endo-4 $\left([\square]^{23}{ }_{\mathrm{D}}=-9.3^{\circ}(c\right.$ $\left.0.8, \mathrm{CH}_{2} \mathrm{Cl}_{2}\right)$ ) matched the literature values for its enantiomer. ${ }^{3}$ The NMR and HMRS data for the major product exo-5 $\left([\square]^{23}{ }_{D}=-2.7^{\circ}\left(c 0.4, \mathrm{CH}_{2} \mathrm{Cl}_{2}\right)\right)$ matched data for the same enantiomer of exo5 synthesized by a different route in our laboratory. ${ }^{4}$

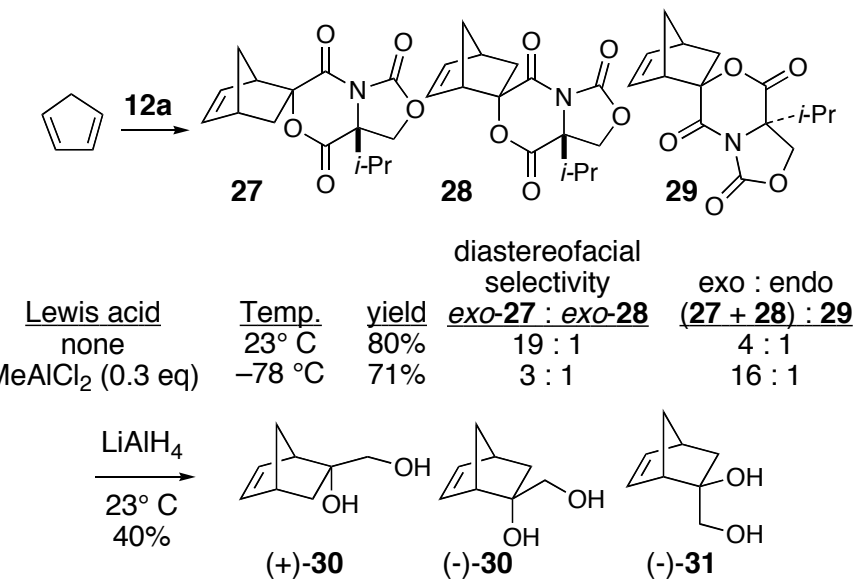

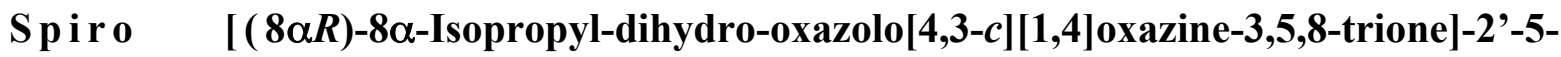
bicyclo-[2,2,1]-hept-5-ene $\left(\mathbf{2 7}, \mathbf{2 8}\right.$, and 29). The thermal Diels-Alder reaction $\left(23{ }^{\circ} \mathrm{C}\right)$ of $\mathbf{1 2 a}$ and SI-11 
cyclopentadiene gave three products in the ratio of $19: 1: 5\left({ }^{1} \mathrm{H}\right.$ NMR analysis), which are inseparable by the chromatography on silica gel: $[\square]^{23}{ }_{\mathrm{D}}=+140^{\circ}\left(c 1.7, \mathrm{CH}_{2} \mathrm{Cl}_{2}\right)$; m. p. $210-$ $211^{\circ} \mathrm{C} ;{ }^{1} \mathrm{H}$ NMR for major diastereomer 27: $\left(500 \mathrm{MHz}, \mathrm{CDCl}_{3}\right) \square 6.51(\mathrm{dd}, J=5.9,3.4 \mathrm{~Hz}, 1 \mathrm{H})$, 6.26 (dd, $J=5.9,2.9$ Hz, 1 H), 4.44 (s, 2 H), 3.44 (br, 1 H), 3.08 (br, 1 H), 2.45 (dd, $J=12.2,3.9$ $\mathrm{Hz}, 1 \mathrm{H}), 2.31(\mathrm{~m}, 1 \mathrm{H}), 2.26(\mathrm{~d}, J=9.3 \mathrm{~Hz} 1 \mathrm{H}), 1.70(\mathrm{~m}, 1 \mathrm{H}), 1.58(\mathrm{dd}, J=12.2,3.4 \mathrm{~Hz}, 1 \mathrm{H})$, $1.09(\mathrm{~d}, J=6.8 \mathrm{~Hz}, 3 \mathrm{H}), 1.05(\mathrm{~d}, J=6.8 \mathrm{~Hz}, 3 \mathrm{H})$ ) $) ;{ }^{13} \mathrm{C}$ NMR $\left(500 \mathrm{MHz}, \mathrm{CDCl}_{3}\right) \square 188.0,167.0$, 166.3, 140.2, 134.6, 91.1, 65.5, 65.0, 54.1, 50.1, 45.6, 42.5, 34.0, 16.2, 14.7; FT-IR (thin film) 2983, $1822,1748,1717,1359,1319,1305,1202,1051,908 \mathrm{~cm}^{-1}$; HRMS (EI) for $\mathrm{C}_{15} \mathrm{H}_{17} \mathrm{NO}_{5} \mathrm{Na}[\mathrm{M}]^{+}$ calcd. 291.1107 , found $291.1107 \mathrm{~m} / \mathrm{z}$.

$\mathrm{LiAlH}_{4}$ reduction of this mixture provided $\mathbf{3 0}$ and $\mathbf{3 1}$ in $4: 1$ ratio. For 30, $[\square]^{23}{ }_{\mathrm{D}}=+89^{\circ}(\mathrm{c}$ $\left.0.08, \mathrm{CH}_{2} \mathrm{Cl}_{2}\right)$, Lit. $[\square]^{23}{ }_{\mathrm{D}}=+118^{\circ}\left(c 2.75, \mathrm{CHCl}_{3}\right) .^{5}$ For 31, $[\square]^{23}{ }_{\mathrm{D}}=-10^{\circ}\left(c 0.02, \mathrm{CH}_{2} \mathrm{Cl}_{2}\right)$, lit. $[\square]^{23} \mathrm{D}=-31^{\circ}\left(c 3.1, \mathrm{CHCl}_{3}\right){ }^{6}$

The Lewis acid catalyzed reaction of $\mathbf{1 2 a}$ and cyclopentadiene $\left(0.3\right.$ eq. $\mathrm{MeAlCl}_{2}, \mathrm{CH}_{2} \mathrm{Cl}_{2}$, $-78{ }^{\circ} \mathrm{C}$ ) provided $\mathbf{2 7}, \mathbf{2 8}$ and $\mathbf{2 9}$ in $12: 4: 1$ ratio. $\mathrm{LiAlH}_{4}$ reduction of this mixture gave $\mathbf{3 0}$ and $\mathbf{3 1}$ in $16: 1$ ratio. For 30, $[\square]^{23}{ }_{D}=+20^{\circ}\left(c 0.18, \mathrm{CH}_{2} \mathrm{Cl}_{2}\right)$.

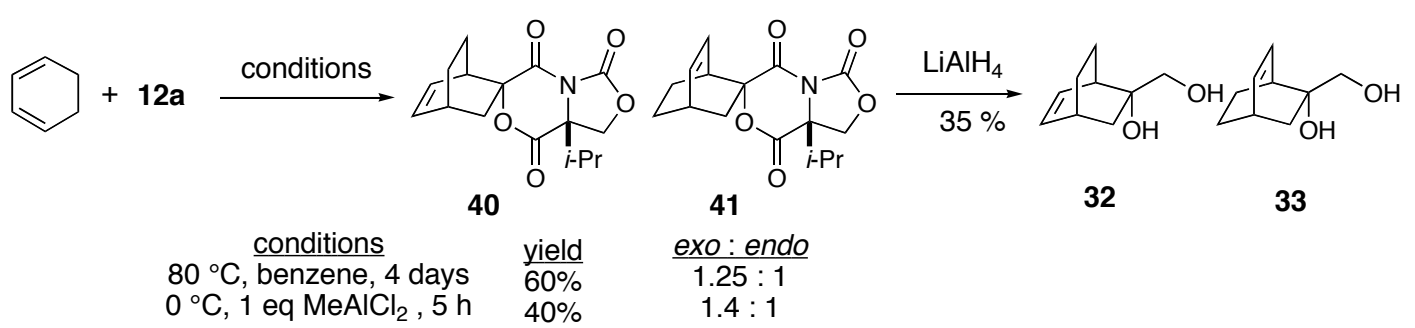

S p i r o $\quad[($ 8 $\square R)$-8马-Isopropyl-dihydro-oxazolo[4,3-c][1,4]oxazine-3,5,8-trione]-2'-5bicyclo-[2,2,2]-octa-5-ene $(40 \& 41)$. The Diels-Alder reactions of 12a and cyclohexdiene provided mixtures of two diastereomeric Diels-Alder products under both thermal and Lewis acid promoted conditions. The major isomer 40 was separated chromatographically: $[\square]^{23} \mathrm{D}=+74^{\circ}(c$ 0.6, $\mathrm{CH}_{2} \mathrm{Cl}_{2}$ ); ${ }^{1} \mathrm{H}$ NMR (500 MHz, $\left.\mathrm{CDCl}_{3}\right) \square 6.40$ (m, $\left.2 \mathrm{H}\right), 4.43$ (m, $2 \mathrm{H}$ ), 3.02 (br, $\left.1 \mathrm{H}\right), 2.84$ (br, 1 H), $2.42(\mathrm{~m}, 1 \mathrm{H}), 2.30(\mathrm{dd}, J=13.2,2.0 \mathrm{~Hz}, 1 \mathrm{H}), 2.17(\mathrm{~m}, 1 \mathrm{H}), 1.73(\mathrm{dt}, J=13.7,2.9 \mathrm{~Hz}, 1 \mathrm{H})$, $1.60(\mathrm{~m}, 1 \mathrm{H}), 1.33(\mathrm{~m}, 1 \mathrm{H}), 1.18(\mathrm{~m}, 1 \mathrm{H}), 1.07(\mathrm{~d}, J=6.8 \mathrm{~Hz}, 3 \mathrm{H}), 1.05(\mathrm{~d}, J=6.8 \mathrm{~Hz}, 3 \mathrm{H}) ;{ }^{13} \mathrm{C}$ NMR $\left(500 \mathrm{MHz}, \mathrm{CDCl}_{3}\right) \quad \square 167.0,165.2,155.9,133.1,132.5,89.2,66.1,65.1,43.0,40.6,36.0$, 
30.3, 22.1, 20.6, 16.1, 15.2; FT-IR (thin film) 2945, 1814, 1750, 1706, 1467, 1360, 1321, 1302, $1191,1102,1050 \mathrm{~cm}^{-1}$; HRMS (ESI) for $\mathrm{C}_{16} \mathrm{H}_{19} \mathrm{NO}_{5} \mathrm{Na}[\mathrm{M}+\mathrm{Na}]^{+}$calcd. 328.1155, found 328.1152 $\mathrm{m} / \mathrm{z}$.

Reduction of the cycloadduct mixture with $\mathrm{LiAlH}_{4}$ provided $\mathbf{3 2}$ and $\mathbf{3 3}$ in $35 \%$ yield.

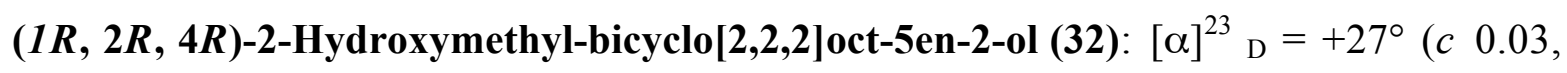
$\left.\mathrm{CH}_{2} \mathrm{Cl}_{2}\right) ;{ }^{1} \mathrm{H}$ NMR $\left(500 \mathrm{MHz}, \mathrm{CDCl}_{3}\right) \square 6.48(\mathrm{t}, J=7.3 \mathrm{~Hz}, 1 \mathrm{H}), 6.24(\mathrm{t}, J=6.8 \mathrm{~Hz}, 1 \mathrm{H}), 3.61(\mathrm{~m}$, $2 \mathrm{H}), 2.81$ (br, $1 \mathrm{H}), 2.65$ (br, $1 \mathrm{H}), 2.07$ (t, $J=6.3 \mathrm{~Hz}, 1 \mathrm{H}), 1.89$ (br, $1 \mathrm{H}), 1.64(\mathrm{~m}, 1 \mathrm{H}), 1.50$ (dd, $J=14.2,2.4 \mathrm{~Hz} 1 \mathrm{H}), 1.36$ (m, 2H), 1.24 (m, $2 \mathrm{H}) ;{ }^{13} \mathrm{C} \mathrm{NMR}\left(500 \mathrm{MHz}, \mathrm{CDCl}_{3}\right) \quad \square 136.8,131.7$, 67.9, 42.0, 37.4, 30.4, 23.6, 20.9; FT-IR (thin film) 3373, 2928, 1447, 1378, 1061, $1022 \mathrm{~cm}^{-1}$; HRMS (ESI) for $\mathrm{C}_{9} \mathrm{H}_{14} \mathrm{O}_{2} \mathrm{Na}[\mathrm{M}+\mathrm{Na}]^{+}$calcd. 177.0891, found $177.0894 \mathrm{~m} / \mathrm{z}$.

$(1 S, 2 R, 4 S)$-2-Hydroxymethyl-bicyclo[2,2,2] oct-5en-2-ol (33): $[\square]^{23}{ }_{\mathrm{D}}=-4.5^{\circ}(c 0.11$, $\mathrm{CH}_{2} \mathrm{Cl}_{2}$ ); ${ }^{1} \mathrm{H}$ NMR $\left(500 \mathrm{MHz}, \mathrm{CDCl}_{3}\right) \square 6.22(\mathrm{~m}, 2 \mathrm{H}), 3.40(\mathrm{~d}, J=10.7 \mathrm{~Hz}, 1 \mathrm{H}), 3.28(\mathrm{~d}, J=10.7$ $\mathrm{Hz}, 1 \mathrm{H}), 2.60$ (br, $2 \mathrm{H}), 2.10$ (m, $2 \mathrm{H}), 1.68$ (m, $2 \mathrm{H}), 1.31$ (m, 3H), $1.15(\mathrm{~m}, 1 \mathrm{H}) ;{ }^{13} \mathrm{C}$ NMR (500 $\left.\mathrm{MHz}, \mathrm{CDCl}_{3}\right) \quad \square 134.3,132.7,69.8,38.7,37.3,30.5,24.6,19.3$; FT-IR (thin film) 3351, 3268, 2940, 2864, 1435, 1324, 1079, $1046 \mathrm{~cm}^{-1}$; HRMS (ESI) for $\mathrm{C}_{9} \mathrm{H}_{14} \mathrm{O}_{2} \mathrm{Na}[\mathrm{M}+\mathrm{Na}]^{+}$calcd. 177.0891, found $177.0892 \mathrm{~m} / \mathrm{z}$.

The stereochemistry of $\mathbf{3 2}$ and $\mathbf{3 3}$ was assigned by ${ }^{1} \mathrm{H}$ nOe studies.

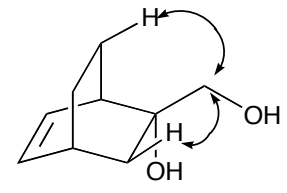

32

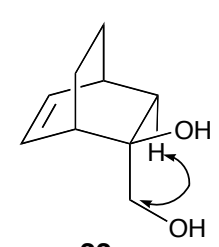

33

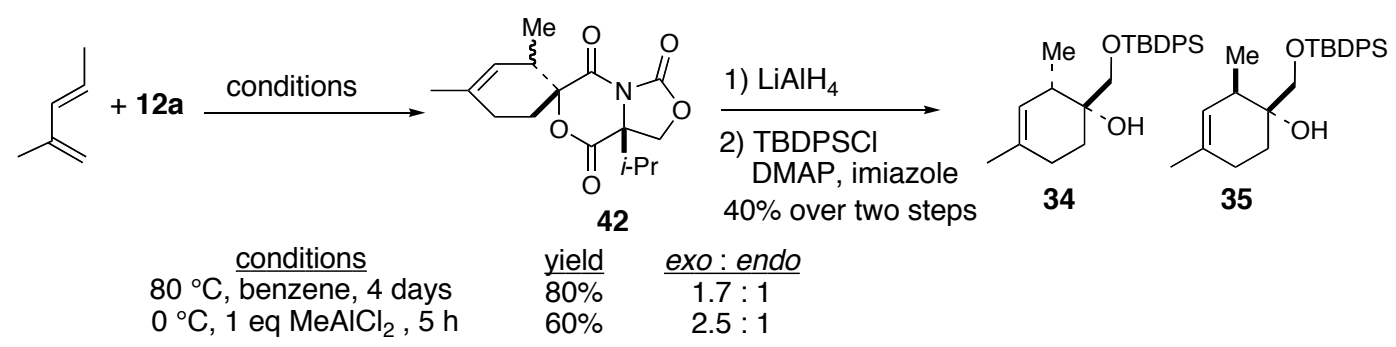




\section{Spiro $\quad[(8 \square R)-8 \square-I s o p r o p y l-d i h y d r o-0 x a z o l o[4,3-c][1,4]$ oxazine-3,5,8-trione]-1'-2,2,4-}

trimethyl-cyclohex-3-ene (42). The Diels-Alder reaction of 12a with trans-2-methyl-1,3pentadiene gave two diastereomers, which were inseparable by chromatography on silica gel: $[\square]^{23}$ $\mathrm{D}=+81^{\circ}\left(c 1.7, \mathrm{CH}_{2} \mathrm{Cl}_{2}\right) ;{ }^{1} \mathrm{H}$ NMR for major diastereomer $\left(500 \mathrm{MHz}, \mathrm{CDCl}_{3}\right) \square 5.12(\mathrm{~s}, 1 \mathrm{H}), 4.43$ (m, 2 H), 2.73 (s, $1 \mathrm{H}), 2.24$ (m, 5 H), $1.71(\mathrm{~s}, 3 \mathrm{H}), 1.10$ (d, $J=6.8 \mathrm{~Hz}, 6 \mathrm{H}), 1.02(\mathrm{~d}, J=7.3 \mathrm{~Hz}, 3$ $\mathrm{H})$ ); ${ }^{13} \mathrm{C}$ NMR (500 MHz, $\left.\mathrm{CDCl}_{3}\right) \square 165.6,163.5,149.4,133.1,122.5,88.7,66.2,65.0,42.0,36.9$, 32.3, 28.3, 22.6, 16.3, 15.5, 15.2; FT-IR (thin film) 2972, 2935, 2281, 1754, 1715, 1460, 1363, 1314, 1190, 1088, $1052 \mathrm{~cm}^{-1}$; HRMS (ESI) for $\mathrm{C}_{16} \mathrm{H}_{21} \mathrm{NO}_{5} \mathrm{Na}[\mathrm{M}+\mathrm{Na}]^{+}$calcd. 330.1317, found $330.1324 \mathrm{~m} / \mathrm{z}$.

$(1 R, 2 S)$-1-(tert-Butyl-diphenyl-silanyloxymethyl)-2,4-dimetyl-cyclohex-3-enol (34) and $(1 R, 2 R)$-1-(tert-butyl-diphenyl-silanyloxymethyl)-2,4-dimetyl-cyclohex-3-enol (35). The mixture diols obtained from $\mathrm{LiAlH}_{4}$ reduction of cycloadducts were inseparable by chromatography. However, conversion of the diol mixture to the corresponding primary TBDPS ethers 34 and 35 enabled the major isomer 34 to be isolated by HPLC ( $7 \%$ EtOAc-Hexane). The

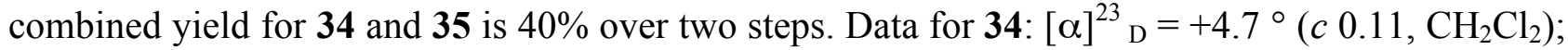
${ }^{1} \mathrm{H}$ NMR $\left(500 \mathrm{MHz}, \mathrm{CDCl}_{3}\right) \square 7.51(\mathrm{~m}, 10 \mathrm{H}), 5.20(\mathrm{~s}, 1 \mathrm{H}), 3.63(\mathrm{~d}, J=10.3 \mathrm{~Hz}, 1 \mathrm{H}), 3.51(\mathrm{~d}, J=$ $10.3 \mathrm{~Hz}, 1 \mathrm{H}), 2.56$ (s, $1 \mathrm{H}), 2.30$ (br, $1 \mathrm{H}), 2.14$ (m, $1 \mathrm{H}), 1.80$ (dt, $J=17.6,5.4 \mathrm{~Hz}, 1 \mathrm{H}), 1.67$ (m, $1 \mathrm{H}), 1.64(\mathrm{~s}, 3 \mathrm{H}), 1.59$ (t, $J=6.3 \mathrm{~Hz}, 1 \mathrm{H}), 1.10(\mathrm{~s}, 9 \mathrm{H}), 0.87(\mathrm{~d}, J=7.3 \mathrm{~Hz}, 3 \mathrm{H}) ;{ }^{13} \mathrm{C}$ NMR $(500$ $\left.\mathrm{MHz}, \mathrm{CDCl}_{3}\right) \square 135.7,135.6,129.8,127.8,125.1,105.0,73.0,67.7,38.4,28.0,27.6,26.9,23.2$, 17.0; FT-IR (thin film) 3436, 2929, 2856, 1464, 1428, 1112, 1064, $823 \mathrm{~cm}^{-1}$; HRMS (ESI) for $\mathrm{C}_{25} \mathrm{H}_{34} \mathrm{O}_{2} \mathrm{SiNa}[\mathrm{M}+\mathrm{Na}]^{+}$calcd. 417.2226 , found $417.2225 \mathrm{~m} / \mathrm{z}$.

For $35{ }^{1} \mathrm{H}$ NMR data: $[\square]^{23}{ }_{\mathrm{D}}=+19^{\circ}\left(c 0.09, \mathrm{CH}_{2} \mathrm{Cl}_{2}\right)$; $77.51(\mathrm{~m}, 10 \mathrm{H}), 5.12(\mathrm{~s}, 1 \mathrm{H}), 3.56$ (m, 2 H), 2.24 (br, 1 H), 2.21 (s, 1 H), 2.12 (m, 1 H), 1.82 (m, 1 H), 1.67 (m, 1 H), $1.62(\mathrm{~s}, 3 \mathrm{H})$, 1.59 (m, $1 \mathrm{H}), 1.09$ (s, 9H), 0.97 (d, $J=7.3 \mathrm{~Hz}, 3 \mathrm{H}) .{ }^{13} \mathrm{C} \mathrm{NMR}\left(500 \mathrm{MHz}, \mathrm{CDCl}_{3}\right)$ ] 135.7, 135.6, 129.8, 127.8, 125.1, 94.8, 72.0, 68.8, 35.2, 28.7, 27.6, 26.9, 19.3, 15.4; FT-IR (thin film) 3436, 2929, 2856, 1464, 1428, 1112, 1064, $823 \mathrm{~cm}^{-1}$; HRMS (ESI) for $\mathrm{C}_{25} \mathrm{H}_{34} \mathrm{O}_{2} \mathrm{SiNa}[\mathrm{M}+\mathrm{Na}]^{+}$calcd. 417.2226 , found $417.2220 \mathrm{~m} / \mathrm{z}$.

The stereochemistry of $\mathbf{3 4}$ and $\mathbf{3 5}$ was assigned by ${ }^{1} \mathrm{H}$ nOe studies. 


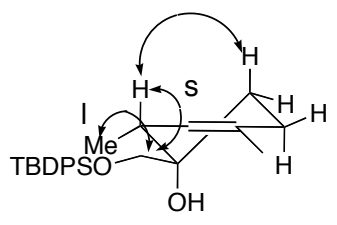

exo

34

I: large nOe signal

s: small nOe signal

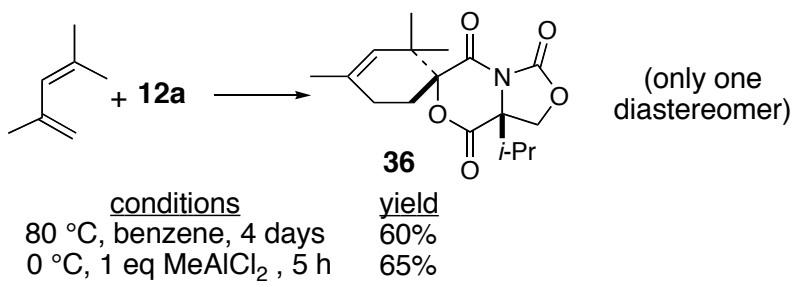

\section{Spiro $\left[\left(1^{\prime} R, 8 \square R\right)-8 \square-I s o p r o p y l-d i h y d r o-o x a z o l o[4,3-c][1,4]\right.$ oxazine-3,5,8-trione]-1'-}

2,2,4-trimethyl-cyclohex-3-ene (36). The Diels-Alder reactions of 12a with 2,4-dimethyl-1,3pentadiene gave only one diastereomer under both thermal and Lewis acidic conditions. Data for 36: $[\square]^{23}{ }_{\mathrm{D}}=+88^{\circ}\left(c \mathrm{c} 0.9, \mathrm{CH}_{2} \mathrm{Cl}_{2}\right) ;{ }^{1} \mathrm{H}$ NMR $\left(500 \mathrm{MHz}, \mathrm{CDCl}_{3}\right) \square 5.05(\mathrm{~s}, 1 \mathrm{H}), 4.44(\mathrm{~d}, J=9.8 \mathrm{~Hz}$, $1 \mathrm{H}), 4.41(\mathrm{~d}, J=9.8 \mathrm{~Hz}, 1 \mathrm{H}), 2.40(\mathrm{~m}, 1 \mathrm{H}), 2.24(\mathrm{~m}, 1 \mathrm{H}), 2.17$ (m, $3 \mathrm{H}), 1.69(\mathrm{~s}, 3 \mathrm{H}), 1.10(\mathrm{~m}$, $12 \mathrm{H}) ;{ }^{13} \mathrm{C}$ NMR $\left(500 \mathrm{MHz}, \mathrm{CDCl}_{3}\right) \quad \square 165.4,165.1,149.4,130.5,128.4,90.8,66.7,65.4,42.0$, 37.4, 28.7, 26.7, 26.5, 24.9, 22.9, 16.1, 15.9; FT-IR (thin film) 2970, 2941, 1819, 1754, 1707, 1352, 1305, 1201, 1188, 1143, $1076 \mathrm{~cm}^{-1}$; HRMS (ESI) for $\mathrm{C}_{17} \mathrm{H}_{23} \mathrm{NO}_{5} \mathrm{Na}[\mathrm{M}+\mathrm{Na}]^{+}$calcd. 344.1474, found $344.1499 \mathrm{~m} / \mathrm{z}$.

\section{References in Supporting Information}

(1) Benneche, T.; Strande, P.; Undheim, K. Synthesis 1983, 762.

(2) Parikh, J. R.; von Doering, E. W. J. Am. Chem. Soc. 1967, 89, 5505.

(3) Roush, W. R.; Barda, D. A.; Limberakis, C.; Kunz, R. K. Tetrahedron 2002, 58, 6433.

(4) Trullinger, T. K.; Roush, W. R. J. Org. Chem. 2006, 71, prepared for submission.

(5) Mattay, J.; Mertes, J.; Maas, G. Chem. Ber. 1989, 122, 327.

(6) Oppolzer, W.; Chapuis, C.; Dupuis, D.; Guo, M. Helv. Chim. Acta 1985, 68, 2100. 